\title{
Production Infrastructure Services as a Factor of the Economic Growth of the Regional Industrial Complex
}

\author{
Adeliya V. Pavlova ${ }^{1,2}$, Mikhail G. Vyukov ${ }^{3} \&$ Sergey V. Kiselev ${ }^{4}$ \\ ${ }^{1}$ Kazan Federal University, Kazan, Russia \\ ${ }^{2}$ Volga Region State Academy of Physical Culture, Sport and Tourism, Kazan, Russia \\ 3 The Center of Advanced Economic Research in the Academy of Sciences of the Republic of Tatarstan, \\ Kazan, Russia \\ ${ }^{4}$ Kazan National Research Technological University, Kazan, Russia \\ Correspondence: Adeliya V. Pavlova, Kazan Federal University, 420008, Kazan, Russia. E-mail: \\ 930895@1ist.ru
}

Received: January 19, $2014 \quad$ Accepted: February 22, $2015 \quad$ Online Published: March 30, 2015
doi:10.5539/res.v7n5p264

\begin{abstract}
In terms of the actualization of the problem of finding effective factors of the economic growth of the national economy the importance of the production infrastructure services is steadily growing as a criterial condition of the economic growth, which is seen as a dynamic system, entirely dependent on the inward investment, aimed at its modernization. The article analyzes the main components of the production infrastructure, their role and importance in the process of its modernization, describes the reasons for the negative dynamics of its development, the modern classification of the factors of the production infrastructure is considered with a critical point of view, affecting the economic growth of the industrial complex of the region; the new trends and patterns are identified, as well as own vision of the factors promoting and hindering the development of the production infrastructure. All of this made a number of important conclusions, including the need to develop the concept of development of the domestic production infrastructure that would seamlessly fit into the framework of the economic growth national hypothesis, institutional preconditions for its development, the formation and development of the state institutions for regulating and monitoring the production infrastructure, the development of a toolkit for public-private partnerships, the development of special laws regulating the production infrastructure as an economic activity, the implementation of measures of the state support for small forms of enterprises in the production infrastructure sectors not related to the sphere of the natural monopolies. The article is intended for researchers, teachers and students in the service economy, studying the research methods in the fields of the production infrastructure in the framework of the disciplines "Service Economy", "Production infrastructure Services", "Production management" as well as managers of the industrial enterprises, elaborating strategies for their development, and specialists of regional governance, dealing with the problems of development of the industrial sector of the regional economy.
\end{abstract}

Keywords: economic growth, production infrastructure, the effect of "multiplier", classification of the factors, infrastructure production, infrastructure services, transport, communications, logistic systems

\section{Introduction}

\subsection{The Relevance of the Problem}

The problems of the domestic economy modernization, the search for effective factors of its economic growth, naturally suggest the importance of the services of the industrial infrastructure as a key condition for the economic growth, which is seen as a dynamic system, entirely dependent on the inward investment, aimed at its modernization (Kondratyev, 2010). Therefore, it is proposed to consider the production infrastructure as a factor of the economic growth not as a static value, all the more so, as its modern options leave much to be desired, but as a phenomenon developing or requiring its development (Kokurin \& Nazin, 2011). Under the development it is proposed to understand, first of all, the investments aimed at developing and modernizing the domestic production infrastructure (Kiselev et al., 2013).

All this necessitates the development and implementation of the institutional order, associated with the formation 
of the concept of the infrastructural development of the country, the regions and municipalities, the formation and development of the state institutions for regulating and monitoring the production infrastructure, the development of a toolkit on public-private partnership, the development of special laws regulating the production infrastructure as an economic activity, the implementation of measures of the state support for small forms of enterprises in the production infrastructure not related to the sphere of natural monopolies (Gilyazutdinova \& Gorelova, 2009).

Only then it is possible to count on deep economic transformations in this area, and, above all, the development of competitive relations in the fields of the production infrastructure, the development of measures to improve profitability of the production infrastructure, creating an attractive investment climate in the production infrastructure, the development and implementation of tools for capitalization growth of the production infrastructure facilities (Kaznacheyev, 2004).

In this regard, the issues on the adequate and qualitative assessment of the impact of the production infrastructure services in terms of the economic growth of the national economy are of particular importance both for the industrial enterprises and the enterprises of the production infrastructure, what is manifested in the preservation of the availability of these services, reduction in the payback periods of the investment projects, creation of the preconditions for the innovative growth (Kalenskaya, 2008).

\section{Methodological Framework}

\subsection{The Research Objectives}

The objectives of this research were to demonstrate the role and value of the production infrastructure as a factor of the economic growth of the industrial complex of the region, analysis of the main components of the production infrastructure, their role and importance in the process of modernization of the domestic economy, the disclosure of the reasons for the negative dynamics of its development, the identification and classification of the factors of the production infrastructure, affecting the economic growth of the industrial complex of the region, identification of new trends and patterns, stimulating and hindering the development of the production infrastructure.

\subsection{Theoretical and Methodological Framework}

The theoretical and methodological framework of the research was based on the works of domestic and foreign scientists in the field of the production infrastructure services development, the assessment of the resource potential of the production infrastructure services of the industrial complex, the specifics of managing the innovative development of the industrial complex production infrastructure, thematic publications in peer-reviewed journals.

In the process of the research the dialectic and system analysis methods were used, as well as methods of scientific abstraction and comparison, of statistical observations, grouping of economic indicators, and methods of modeling and expert evaluations.

\section{Results}

3.1 The Components of the Production Infrastructure of the Industrial Complex of the Region Have Been Grounded, and the Dynamic Parameters of Developing the Production Infrastructure Sectors Have Been Investigated, Having Made It Possible to Identify Certain Trends

The analysis of the theoretical aspects of the problem led us to the hypothesis, namely, that the production infrastructure of the industrial complex of the region can be classified into the following components, which will allow us, in order to implement the objectives of the research, to assess the impact of each of the classification characteristic on the parameters of the economic development of the industrial complex of the region. The proposed classification can be as follows:

- Infrastructure production: production and distribution of electricity, gas and water. Due to the fact that according to statistics of the energy balance of Russia, the share of population in total electricity consumption accounts for just over $10 \%$, then $90 \%$ of this amount is consumed in the industrial and social infrastructure. Similar parameters of consumption are applicable to gas and water resources;

- Infrastructure services: transport and communications.

According to experts (Kokurin \& Nazin, 2011) more than $80 \%$ of the resource cost of the production infrastructure accounts for these types of infrastructure production and services, which gives us every reason to base on these data in forecasting trends and regularities of the development and influence of the production infrastructure on the economic growth of the industrial complex of the region. 
However, in modern Russian economic literature the focus from the point of view of investment preferences is given, for some reason, to investment in the development of passenger transport, which significantly inhibits the development of the production infrastructure as a form of the economic activity, largely providing for all the same needs of the population.

According to the calculations made on the basis of the official statistical sources, it can be concluded that the investment amounts in the production infrastructure industry, which is not related to passenger transport maintenance, are constantly decreasing (see table 1).

Table 1. Dynamics of commissioning the production infrastructure facilities in Russia in the period from 1995 to 2011

\begin{tabular}{llllllll}
\hline & 1990 & 1995 & 2000 & 2005 & 2008 & 2010 & 2011 \\
\hline $\begin{array}{l}\text { Turbine power plants, million kW } \\
\begin{array}{l}\text { Power transmission lines, thousand } \\
\text { km }\end{array}\end{array}$ & 0.3 & 0.4 & 0.8 & 0.8 & 0.6 & 0.8 \\
Paved highways, thousand km & 12.8 & 7.5 & 2.6 & 2.3 & 2.4 & 2.0 & 2.1 \\
Water supply networks, & 7.5 & 2.6 & 1.4 & 1.5 & 2.0 & 2.0 & 2.1 \\
$\begin{array}{l}\text { Sewernetworks, thousand km } \\
\text { Heat supply networks, thousand km1.5 }\end{array}$ & 0.9 & 0.5 & 0.2 & 0.1 & 0.3 & 0.1 & 0.2 \\
$\begin{array}{l}\text { Hard-surface runways, thousand } \\
\text { cubic m. }\end{array}$ & - & 0.2 & 0.2 & 0.3 & 0.2 & 0.2 \\
\hline
\end{tabular}

The sources: compiled by the authors on the basis of the official statistical data.

As shown by the official statistics, over the past 18 years, the construction of power plants has fallen by more than four times, the length of the newly constructed transmission lines-by twice, the length of the commissioned auto-roads with hard surface-by four times, the length of the commissioned water supply networks - by 3.5 times, the sewer — by 3 times, heat supply networks — by 5 times, paved runways - by almost 10 times.

All this suggests a certain tendency that is associated with the reduction of the production infrastructure sectors' capacities over the past 20 years.

\subsection{The Synergetic Effect and the Methodological Approaches to the Assessment of the Production Infrastructure Impact on the Economic Growth and the Modernization of the Domestic Economy Have Been Substantiated}

The analysis results show that the investments in the production infrastructure facilities can be identified as tools for forming and developing the terms of the points of the economic growth, creation of new jobs. A number of researchers consider the investment flows into the production infrastructure as the most effective instrument of redistribution of resources from industries with excess capacities to which they refer the manufacturing industries, capable of sustainable economic growth. According to experts, public capital investments in the infrastructure stimulate private investments, with each dollar spent on the infrastructure projects causing a multiplier effect in the size of 1.59 USD (Kondratyev, 2010).

Due to the fact that for the purposes of our survey it is necessary to assess the degree of the production infrastructure influence on the economic growth of the industrial complex of the region, let us focus on the types and methods of assessing this influence.

So, in the economic literature there are two main methods of measuring the infrastructure parameters, including physical and cost ones. The cost indicator reflects the parameters of the accumulated investments or the accumulated capital in the individual branches of the infrastructure production, for example, the production volumes of electrical energy, gas and water, or commissioning of power plants, new railway lines, highways, transmission lines, etc.

The analysis of the research materials (Tretyak, 2001; Kokurin \& Nazin, 2011; Kiselev et al., 2013) allows selecting five main types of the production infrastructure impacts on the economic growth of the regional industrial complex: 
- In a form of direct exposure as a factor of production;

- In a form of replacement of other factors of production;

- In a form of stimulating the processes of the production factors accumulation;

- In a form of stimulating the aggregate demand;

- In a form of a tool of the industrial policy.

Obviously, in the form of direct exposure as a factor of production there can be separate branches of the production infrastructure, such as, for example, electric power and transport, whose participation in the production process is due to their direct contribution to the production process and the creation of the added value.

At the same time, the production infrastructure can both facilitate and hinder the production process. So, unreasonably high transport costs or even the lack of adequate transport services can lead to a substantial increase in production costs and decrease in the enterprise competitiveness.

On the other hand, the modern high-efficiency system of the production infrastructure services can significantly reduce the costs of enterprises, providing them with reliable and affordable communication, adequate logistic services, access ways and high-quality highways. Thus, the establishment of a number of cluster formations in the Republic of Tatarstan has become possible only due to the highly developed production infrastructure, formed around such major corporations as OJSC "KAMAZ" or JSC "Tatneft".

Quite obviously, the development of the production infrastructure sectors has a pronounced synergistic effect, and the effect of "multiplier". Thus, the development of transport systems will actively encourage the development of means of communication, and the formation of broad and high-quality network of roads will lead to the promotion of transport services, and vice versa. Therefore, the infrastructure sectors are very closely interconnected and the development of some leads to active growth of the others. The effect of "multiplier" may occur in situations where the inception of major infrastructure projects is usually accompanied by massive investment flows in construction, then in the repair and reconstruction of these structures, which are required to maintain their operable condition. All this stimulates the aggregate demand for the products of other industries, such as petrochemical, metallurgy, building materials industry, consulting services, outsourcing, information and communication services, and others. According to experts, every billion dollars invested in the infrastructure creates directly 15 thousand jobs and about 30 thousand additional jobs in the sectors related to the infrastructure (Sulakshin, 2005).

In turn, budget investments in the infrastructure facilities are an active stimulus to the development of the public-private partnership, when, for example, the construction of a large industrial park stimulates small and medium enterprises to innovative activity and improving their competitiveness, and the construction of roads in rural areas can enhance the appearance of peasant (farming) households and attraction of private capital into the sphere of services in this area. Eventually, all this will contribute to economic growth in this region (Kiselev et al., 2013).

However, quite obvious are the feedbacks in this process, when the economic growth stimulates demand for products of the infrastructure production and services. This directly can be attributed to both the production and distribution of electricity, gas and water, and the transportation and communication services. So, for example, a sharp increase in traffic flows in the Volga region has required the development and construction of one of the largest in Russia "Sviyazhsk interregional multimodal logistics centre", the funding of which was carried out only at the expense of the budget funds. The complex included the railway auto-terminal, with warehouses and container platforms, the river port with a water-car terminal, access tracks and roads, loading areas, service facilities.

In other words, the interconnectedness and synergy of the infrastructure production and services industries greatly increases the economic efficiency of the capital investments in this area and their investment attractiveness.

\subsection{The Importance of the Transport Infrastructure as the Dominant Factor in the Economic Growth of the Regional Industrial Complex Has been Substantiated}

However, according to experts, not all the sectors of the infrastructure production and services are capable to equivalently affect the economic growth of the regional industrial complex. The majority of the experts (Sulakshin, 2005) are unanimous in the opinion that the dominant influence on the economic growth has the present well-developed and high-quality road network. However, it is difficult to agree with such a unilateral 
approach to such a complex phenomenon, which is the production infrastructure. Obviously, the construction of highways linking a particular region with the centers of the economic growth without supporting it in a parallel way and adequately with generating capacities, gasification, transportation, telecommunications and many other attributes of the infrastructural character, will significantly reduce the expected economic effect.

Foreign countries are significantly ahead of Russia in the pace and scale of the construction of railways and roads, giving them priority among other types of the infrastructural support. Thus, according to the "International Union of Railways", Russia, in terms of the construction volume of these roads is inferior to Brazil and is on par with India (Kondratyev, 2010).

The leading positions in the construction of the high-speed railways are occupied by China, which is planning to build 13 thousand $\mathrm{km}$ by 2025, it is followed by Spain -5.5 thousand $\mathrm{km}$, France -4.9 thousand $\mathrm{km}$. Significantly behind the three leaders are the U.S., planning to build by 2025 only 1.5 thousand $\mathrm{km}$ of high-speed railways, Brazil— 0.8 , Russia -0.7 and India -0.7 thousand $\mathrm{km}$ (Kondratyev, 2010).

As evidenced by the analytical data of the international consulting companies for the development of "National Infrastructure Plan 2010" infrastructure, if China, since 2000-ies, invests 8-10\% of GDP in the infrastructure, and India- 4-6\%, Russia will barely reach 1-2\%, being at the level of Latin American countries. According to the experts of these companies, Russia's needs in the infrastructure investments (including oil and gas investments) constitute approximately \$ 36 billion a year. In other words, by 2014 the volume of the infrastructure investments would have reached 120 billion dollars, i.e. would have increased from 1\% in 2010 to $6 \%$ in 2014. The other BRIC countries have already long been spending 6-8\% of GDP on the development of their infrastructure (China- $8 \%$, Brazil and India-4-6\%) (National Infrastructure Plan, 2010.).

\subsection{Factors Stimulating and Inhibiting the Development of the Production Infrastructure Facilities of the Region's Industrial Complex}

In the process of the research on the impact of the production infrastructure on the economic growth of the industrial complex of the region with an objective need there emerges the question about the factors stimulating and inhibiting this impact. In the national economic literature most authors identify such factors, influencing the formation, the dominant sectoral composition and the directions of development of the production infrastructure, as economic, social, legal, naturally-geographical, technological (Kaznacheyev, 2004). However, others (Gilyazutdinova \& Gorelova, 2009) believe that it is timely and relevant to add to this classification the organizational-administrative factors that are associated with the exposure of the adopted formal model of the production infrastructure facilities economic management, the level of development of regulatory institutions for the infrastructure economic activities.

Some authors, instead of the social, suggest identifying the socio-cultural factors, and instead of the legal-the political-legal. However, as it is quite obvious, these adjustments in the classification of the factors are not essential to their substantial characteristics. Within this classification, in accordance with the scope of application, all the factors are divided into the outer, arising in the economic system of the region, or outside of the production infrastructure facilities, and internal, arising at the level of the production infrastructure facilities of the industrial complex. Some authors classify the factors of direct and indirect impacts, as well as the stimulating and hindering ones (Brusakova, 2010).

It is quite obvious that the group of basic natural and geographical factors determines the impact of the natural and climatic conditions, geographical location, environmental characteristics and resource potential, which have a direct or indirect impact on the production infrastructure system (Osborne, 2008). Thus, the climatic conditions and the availability of natural resources determine the structure of the industrial complex, its priority sectors, the nature and structure of the transport system, the share of the pipeline, rail, highway and air transportation, the exporting or importing structures of the power supply system, the need for logistics centers, et cetera. Thus, the dominance of the oil-producing, oil-refining industries in the structure of the industrial complex of the Republic of Tatarstan causes also the nature of the transport system, its components, the structure of the energy balance, and much more.

The second most important impact on the parameters of the production infrastructure are, of course, the economic factors, which are conventionally divided into internal and external, which substantially eliminates the significance of this division. Thus, the diversity of forms of ownership, the investment attractiveness of the region's economy, the developed system of competition, the sound tax policy and the effective state system of support for small enterprises can both stimulate and significantly inhibit the development of the production infrastructure facilities. At the same time, the influence of these external factors on the average industry costs in the production infrastructure, the level of the entrepreneurial activity of small forms of enterprises in the sectors 
of the services infrastructure, as well as the height of the administrative barriers for the entities of the production infrastructure are quite obvious (O’Flynn, 2009).

But the most characteristic indicator of the production infrastructure adequacy to the level and pace of the economic growth is the ratio of its growth rates with GDP growth rates (see table 2).

Table 2. Dynamics of GDP growth rates and the major sectors of the production infrastructure of Russia in the period from 2000 to 2010 (in percent)

\begin{tabular}{lccccccc}
\hline & 2000 & 2005 & 2006 & 2007 & 2008 & 2009 & 2010 \\
\hline $\begin{array}{l}\text { Grossdomesticproduct } \\
\begin{array}{l}\text { Production and distribution } \\
\text { electricity, gas and water }\end{array}\end{array}$ & 110.0 & 106.4 & 108.2 & 108.5 & 105.2 & 92.2 & 104.0 \\
\begin{tabular}{l} 
Transportandcommunications \\
\hline
\end{tabular} & 103.7 & 103.7 & 101.9 & 97.5 & 102.1 & 96.3 & 98.9 \\
\hline
\end{tabular}

The source: compiled from the official statistics

According to the official statistics, over the last ten years almost throughout the entire period, except for two years of the financial crisis, the growth rates of the main production infrastructure sectors, which we refer to the production and the distribution of the electric power, gas and water, transport and communications lagged in growth rates from GDP parameters, indicating their inadequate development associated with the slowdown in the economic growth rates of the national economy.

The group of technical and technological factors determines the state of the material-technical base of both the production infrastructure, and the entire regional industrial complex. It is obvious that the technical-technological parameters of the production infrastructure will be a little different depending on the regions of Russia. This primarily concerns the high level of depreciation of the fixed assets of the heat, utilities and energy networks. Thus, the degree of depreciation of the fixed assets in the Russian infrastructure sector "Production and distribution of electric power, water and gas" for the period from 2005 to 2011 has almost not changed and amounts to over 50\%. In this case, the increase in the rate of the renewal of the fixed assets looks like a positive trend in this infrastructure sector from $2.1 \%$ in 2005 to $4.2 \%$ in 2011. In turn, the index of the industrial production for this type of the economic activity was only $100.1 \%$ in 2011 ; the average annual growth rate of the freight turnover did not exceed $0.3 \%$, while GDP grew during the same period by $104 \%$ (Russian statistical yearbook, 2011).

\subsection{A Classification of Factors Promoting and Inhibiting the Development of the Production Infrastructure Has Been Offered}

We believe it is reasonable to classify the factors stimulating and inhibiting the formation and development of the production infrastructure, which we presented in table 3. It is obvious that the actual inhibiting factors in the development of the production infrastructure largely exceed the capacities of the stimulating factors, which are mainly presented in a form of potential substances. Naturally, this is exactly due to the low level of development of the domestic production infrastructure.

Table 3. The classification of the most important factors stimulating and inhibiting the development of the production infrastructure facilities

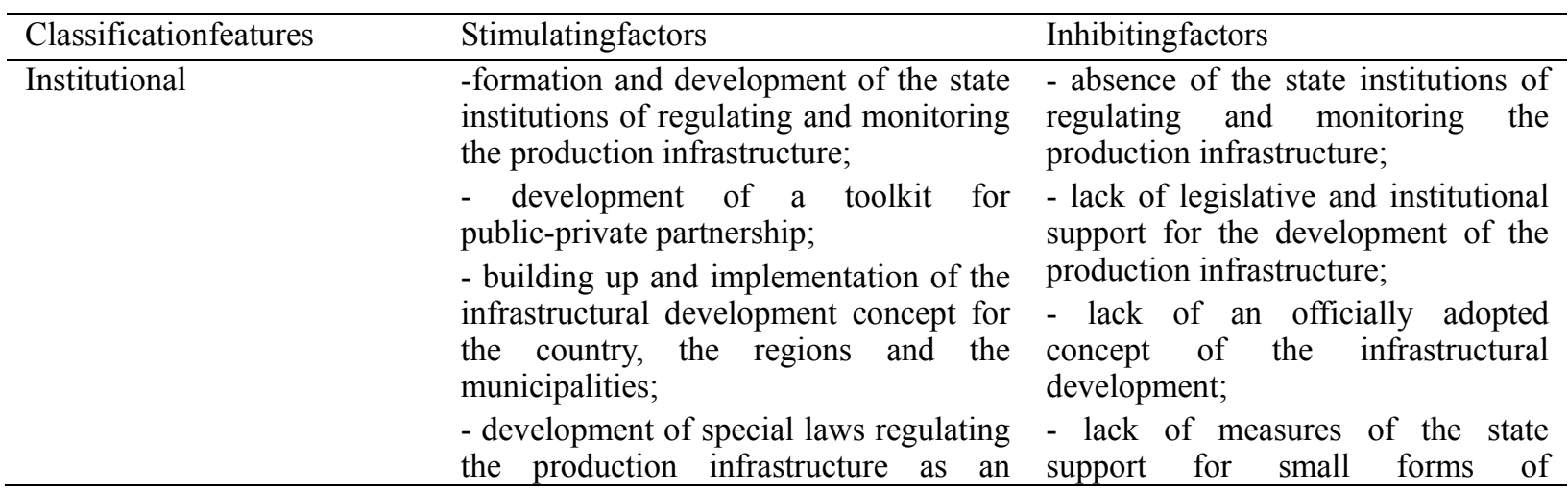


economic activity;

- implementation of measures of the state support for small forms of enterprises in the production infrastructure sectors not related to the sphere of the natural monopolies;

Economic

Technical-Technological

Organizational-administrative climate in the production infrastructure
- development of competitive relations in the fields of the production infrastructure, not related to the sphere of natural monopolies;

- development of measures to improve profitability of the production infrastructure facilities;

- implementation of measures of the state guarantees for borrowing funds to implement major infrastructure projects;

- creation of an attractive investment sectors;

- development and implementation of tools for capitalization growth of the production infrastructure facilities.

- development and implementation of the industrial policy in the sphere of the production infrastructure;

- development and implementation of the innovative policy in the sphere of the production infrastructure;

- accelerated updating of the fixed assets of the production infrastructure;

- use of the toolkit of "borrowing" the infrastructure support foreign technology;

- formation of the own innovative development database.

- development of the economically feasible methods to determine the ratio of the production and infrastructure sectors;

- development of the cross-sectoral infrastructure balances;

- development of the economically feasible methods for determining the cross-sectoral correlation of the infrastructure production and the infrastructure services;

- implementation of international standards in the practice of the production infrastructure;

- mandatory retraining and advanced training of the managerial staff. enterprises in the production infrastructure sectors, not related to the sphere of the natural monopolies;

- no special system of the statistical monitoring;

- lack of demand for the products of the production infrastructure in the domestic market;

- a high level of the financial risk in implementing major infrastructure projects;

- a long payback period for infrastructure projects;

- lack of domestic financial resources for development;

- unreasonably high interest rates on loans taken to replenish even the working capital;

- absence of tax preferences;

- investment insecurity;

- underdeveloped financial infrastructure.

- lack of industrial policy in the sphere of the production infrastructure;

- lack of innovative policy in the sphere of the production infrastructure;

-a high degree of depreciation of buildings, structures and equipment;

- lack of the resources to develop innovative products;

- progressive depreciation of the productive assets;

- a low level of the renewal of the fixed assets;

- a low level of the legal protection of entrepreneurship in the sphere of the production infrastructure;

- "the blurring of the property rights" in the major subjects of the production infrastructure in the sphere of the natural monopoly;

- a low level of personnel training;

- lack of specialized educational institutions for training and retraining the managerial personnel in the field of the production infrastructure. 


\subsection{The Necessity for Building up a Concept for Developing the Domestic Production Infrastructure Has Been Substantiated}

In this regard, the key-pillar should be made of building up a concept at the government level of developing the domestic production infrastructure, in which there shall be formulated the main hypothesis of its development, identified the priorities and objectives, disclosed the methods and tools to implement those tasks, including institutional, financial, investment and organizational-administrative. Only a comprehensive, complete understanding of the development vector for the domestic production infrastructure will help avoiding the most currently common, simple and cheap method of implementing some certain, albeit very large, infrastructure projects, however, which may not fit into the conceptual framework of the national hypothesis.

The current regional disunity today in the implementation of the infrastructure projects has a negative impact on the investment attractiveness of both the entire complex as a whole and its individual sectors. All this hinders the investment activity of the production infrastructure subjects, depriving them of the state guarantees for the borrowings, pushing on "predatory" bank loans in their interest rates, even under current assets. As a result, the volume of non-payments, overdue receivables and payables are growing like a snowball, which naturally leads to a general deterioration of not a stable financial position of the production infrastructure subjects.

Hence, the highest priority among the stimulating measures there should be the institutional order measures associated with the development and implementation of the concept of the infrastructural development of the country, the regions and municipalities, the formation and development of the state institutions for regulating and monitoring the production infrastructure, the development of a toolkit for public-private partnership, development of special laws regulating the production infrastructure as an economic activity, the implementation of measures of the state support for small forms of enterprises in the production infrastructure industries, not related to the sphere of natural monopolies.

Only after the implementation of the institutional component of the concept for developing the domestic production infrastructure there must begin deep economic reforms in this area, and, above all, the development of competitive relations in the fields of the production infrastructure, not related to the sphere of the natural monopolies, development of measures to improve profitability of the production infrastructure facilities, the implementation of measures of the state guarantees for borrowing of funds for the implementation of major infrastructure projects, creating an attractive investment climate in the production infrastructure sectors, development and implementation of tools for capitalization growth of the production infrastructure facilities.

The results of these economic reforms should consist in development and implementation of the industrial policy in the sphere of the production infrastructure, development and implementation of the innovative policy in the sphere of the production infrastructure, accelerated renewal of the fixed assets of the production infrastructure, use of the tools of "borrowing" the foreign technologies of the infrastructure support, formation of the innovative development own database.

As the organizational-administrative component, designed to carry out a regulatory impact on the emerging production infrastructure system, there should be development of the economically feasible methods for determining the ratio of the production and the infrastructural sectors, development of the cross-sectoral infrastructure balances, development of the economically feasible methods for determining the cross-sectoral correlation of the infrastructure production and the infrastructure services, introduction of the international standards in the industrial infrastructure practices, mandatory retraining and advanced training of the managerial staff.

Thus, the proposed algorithm for forming and developing the system of the production infrastructure, based on the analysis of factors influencing its parameters, allows implementing a comprehensive approach to the solution of problems of developing the production infrastructure, which aims to create a fully sustainable economic mechanism of the system's functioning in terms of the disturbing impacts of the external environment, to which the production infrastructure is susceptible as not to any other economic activity.

\section{Discussions}

The research works of Gilyazutdinova and Gorelova (2009), Kondratiev (2010), Kokurin and Nazin (2011), Kiselev and Faizrahmanov (2013), Sulakshin (2008) and others are devoted to the analysis of the problems of forming and developing the production infrastructure services and their role in the economic growth.

The proceedings of Brusakova (2010), Kaznacheyev (2004), Kalenskaya (2008), Tretiak (2001), O'Flynn (2009), Osborne (2008) and others are devoted to the study of the factors affecting the rapid development of the production infrastructure sectors in the conditions of modernization of the national economy. 
However, a number of issues relating to the classification of factors promoting and inhibiting the development of the production infrastructure sectors, as well as to the need of building up the concept of developing the domestic production infrastructure, and other institutional factors of its development, remain poorly studied.

\section{Conclusion}

Thus, the analysis of the processes of forming and developing the services of the production infrastructure as a factor of the economic growth of the industrial complex of the region, allows drawing the following conclusions. The problems of modernization of the domestic economy, the search for effective factors of its economic growth, naturally stimulate the intensification of the scientific research in the area of the production infrastructure services as a key condition for the economic growth.

The results of the conducted research allowed us to validate the components of the production infrastructure of the industrial complex of the region and to determine the dynamic parameters of developing the production infrastructure sectors, which enabled us to identify certain trends. In addition, the synergetic effect and the methodological approaches to the assessment of the impact of the production infrastructure sectors on the economic growth parameters and the modernization of the domestic economy were justified, including the transport infrastructure as the dominant factor in the economic growth of the industrial complex of the region, the factors promoting and hindering the development of the production infrastructure facilities of the industrial complex of the region have been identified and their classification has been proposed for the purposes of establishing adequate managerial solutions, as well as the necessity for building up the concept for developing the domestic production infrastructure has been substantiated.

\section{Recommendations}

The obtained results allow explaining, classifying and structuring the basic directions of using the potential of the enterprises of the production infrastructure as the most important factor of the economic growth of the regions, as well as evaluating its impact on the industrial structure of the domestic economy as a whole, its individual regions. In addition, the obtained results can be useful to the state administration bodies in the improvement of the national industrial policy in regulation of the processes of forming and developing the production infrastructure sectors of the regions and Russia as a whole.

\section{References}

Brusakova, I. A. (2010). Organization and management of the infrastructure of the industrial production: Informational aspect. St. Petersburg, Publishing house of the Polytechnic University.

Gilyazutdinova, I. V., \& Gorelova, E. N. (2009). The influence of the organizational-economic transformations on the innovative activity in the sphere of the production infrastructure. Bulletin of Kazan University of technology, 5, 123-131.

Kalenskaya, N. V. (2008). The formation of the infrastructure model of the innovative development of the production clusters (in the framework of the institutional approach). Kazan: Publishing house of the KSU.

Kaznacheyev, V. A. (2004). The production infrastructure as a factor of sustainable development of the regions. Moscow: Translit

Kiselev, S.V., Gilyazutdinova, I. V., \& Faizrakhmanov, M. D. (2013). The interaction of the state and business structures as a condition for innovative development of the production infrastructure in the services sector. Bulletin of the Kazan technological University, 4, 340-346.

Kokurin, D. I., \& Nazin, K. N. (2011). Formation and implementation of the infrastructure capacity of the Russian economy. Moscow: Publishing House "Translit".

Kondratyev, V. B. (2010). Infrastructure as a factor of the economic growth. A fund of the historical perspective. Retrieved from http://www.perspektivy.info

National Infrastructure Plan. (2010). Information Policy Team, The National Archives, Kew, London.

O’Flynn, K. (2009). Russia's infrastructure falling apart. RFE/RL Newsletter.

Osborne, S. (2008). Russian Infrastructure: The Big Picture. Asian Investor.net.

Russian statistical yearbook. (2011). Stat. coll (p. 795). Rosstat, Moscow.

Sulakshin, S. S., Vilisov, M. V., \& Khrustalev, E. A. (2005). The public-private partnership in the road sector. Moscow: Scientific expert.

Tretiak, S. N., \& Shukovskaya, M. A. (2001). The production infrastructure in the national economy of Russia. 
Khabarovsk: Publishing house of FESTU.

\section{Copyrights}

Copyright for this article is retained by the author(s), with first publication rights granted to the journal.

This is an open-access article distributed under the terms and conditions of the Creative Commons Attribution license (http://creativecommons.org/licenses/by/3.0/). 